\title{
THE SUBMICROSCOPIC STRUCTURE OF ARTICULAR CARTILAGE IN THE ADULT PIG
}

\author{
D. HORKÝ \\ Department of Anatomy, Histology and Embryology \\ University of Veterinary and Pharmaceutical Sciences, 61242 Brno
}

Received fune 16, 1992

\begin{abstract}
Horký D.: The Submicroscopic Structure of Articular Cartilage in the Adult Pig. Acta vet. Brno, 62, 1993: 9-18.

Articular cartilage collected from the femoral heads of 5 adult pigs of both sexes, aged 14-24 months, was studied by light microscopy and transmission and scanning electron microscopy.

Chondrocytes of the surface layer were oval in shape and sent out short projections into the surrounding pericellular matrix. Their cytoplasm contained numerous lysosomes, transport vacuoles, centrioles and a well-formed Golgi apparatus and small deposits of glycogen. They were arranged in rows or tiers.

Chondrocytes of the middle layer were oval cells enclosed by pairs in lacunae. Their nuclei had 1-2 nucleoli of reticular type. The zonula nucleum limitans was well developed. The cytoplasm contained a large number of mitochondria, cisternae of the granular endoplasmic reticulum, a large Golgi field, numerous transport vacuoles, lysosomes and conspicuous glycogen deposits.

In the transitional zone, chondrocytes were arranged in tiers perpendicular to the surface. They were smaller in size and the cytoplasm contained, apart from the typical organelles, large bundles of intermediate filaments. Chondrocytes of the deep layer could be distinguished into those characterized by conspicuously large lipid vacuoles and those with homogeneous cytoplasm and small glycogen deposits.

The pericellular matrix was well developed in the majority of chondrocytes; in the regions where it was missing the cell membrane was in contact with the intercellular matrix. In the middle layer, cell detritus was seen at the border between pericellular and intercellular matrix
\end{abstract}

Submicroscopic structure, articular cartilage, adult swine

Articular cartilage is an avascular, alymphatic and aneural tissue lining the articular bone surface. Like other connective tissues it consists of cells - chondrocytes - deposited in an abundance of the intercellular matrix. The chondrocytes account for only $0.01-0.1 \%$ of the total cartilage volume. The intercellular matrix is made up of collagenous fibres, proteoglycans, and organic and inorganic components. A proper function of the articular cartilage depends on its mechanical properties permitting it to a) transfer and distribute high pressure forces upon the subchondral bone; b) maintain the constant load at a relatively low level; c) facilitate movement at minimal friction (Wright 1969; Freeman and Kempson 1973; Maroudas 1973; Chappuis et al. 1983; Swann et al. 1984).

Resistance to pressure in cartilage is secured by the structure and arrangement of the intercellular matrix in both its parts (Weiss et al. 1968; Clarke 1974; Bloebaum and Wilson 1980; Horký 1980; Ghadially 1983; O’Connor et al. 1948; Clark 1990). The chondrocytes havea minimal involvement in the mechanics of articular movement but play a key role in the synthesis. of intercellular matrix which is responsible for the mechanical properties of cartilage and the sliding and lubrication of contact surfaces (Maroudas 1973; Ghadially 1983; Palmoski and Brandt 1984; Poole et al. 1988; Buckwalter et al. 1989; Copf and Czarnetzki 1989; Fife 1989).

Articular cartilage arises from mesenchyma during the skeletal development as a part of car- 
tilaginous blastema of the bone rudiment. The pre-formed bone rudiment is gradually eroded but articular cartilage is affected by neither this nor the following ossification process and remains as a thin layer on the articular surface (Bonucci 1967; Hanaoka 1976).

The condensation of mesenchyma in the blastema takes place in the early embryonic development and in man, according to Gardner and O'Rahilly (1968), chondrification of the femur is commenced at 6 weeks and the articular cavity appears as a differentiated groove produced by mesenchymal blastema of the bone rudiment at 8 weeks (Ghadially 1983). Our results suggest that by this time articular cartilage has been completed (Horký 1991a, b). However, data on articular cartilage differentiation in lower mammals, apart from cattle (Horký 1986), have not been reported in the literature.

The differentiation events leading to the formation of articular cartilage before birth, and eventually producing the highly specialized tissue after birth, are called the maturation process. They are determined by genetic, endocrinologic and nutritional factors (Grondalen 1974c; Silberger et al. 1961; Grondalen 1979a, d, e, f) to which the effects of endogenous environments are added in the postnatal period (Ghadially 1981; Perrin et al. 1987; Wilsman et al. 1981). Changes in the morphology of articular cartilage are most frequently related to age. They have been amply documented in mice (Silberger et al. 1976), rats (Mark et al. 1998), rabbits (Davies et al. 1962; Barnett et al. 1963), dogs (Lust et al. 1972; Lust and Sherman 1973; Wiltberger and Lust 1975; Fife 1989), cattle (Horký 1983, 1987; Neame et al. 1989; Kiefer et al. 1989) pigs (Grondalen 1974b, c, f; Nakano et al. 1979a, b; Horký 1989) and man (Horký 1980, 1991a, b; Ghadially 1983). From the studies concerning porcine articular cartilage, information on its ultrastructure under physiologic conditions has been provided only by the paper of Bhatnagara et al. (1981), who investigated pigs 20 to 30 weeks old, and by our earlier work (Horký 1991d) on porcine articular cartilage in the early postnatal period.

Some of the above mentioned studies have also been concerned with pathological findings at the lumbosacral junction (Doige 1980) or with the growth plate in relation to age (Nakano et al. 1982; Farnum et al. (1984).

The ultrastructure of articular cartilage of the adult pig, which so far has not been studied, is dealt with in this communication.

\section{Materials and Methods}

Articular cartilage was collected from the femoral heads of 5 pigs aged 14-24 months to be :studied by light microscopy and transmission and scanning electron microscopy.

For transmission microscopy, the tissue samples were further dissected to obtain strips, 1 by 1 by $3 \mathrm{~mm}$ in size, which were immediately fixed in a glutaraldehyde solution ( $400 \mathrm{mmol} / 1$ in $0.1 \mathrm{M}$ phosphate buffer, $\mathrm{pH}$ 7.4). The tissue was then decalcified with $0.1 \mathrm{M}$ EDTA in 400 mmol/1 solution of glutaraldehyde, $\mathrm{pH} 7.2$, applied twice for $60 \mathrm{~min}$., and then left in the solution overnight. In the last bath it was kept for $75 \mathrm{~min}$. and then rinsed in 4 consecutive baths of $0.1 \mathrm{M}$ phosphate buffer, pH 7.4 (30 min. each) and fixed in two baths of $40 \mathrm{mmol} / 1$ solution of $\mathrm{OsO}_{4}$ in phosphate buffer, $\mathrm{pH}$ 7.4. Semithin sections for light microscopy observations were prepared by standard techniques (dehydration, immersion and embedding in Durcupan ACM) and stained with methylene blue and Azure II. Ultrathin sections were made using an ultramicrotome (Ultracut Reichert), stained with either lead citrate alone or uranyl acetate and lead citrate, and examined and photographed with a Tesla BS 500 electron microscope.

\section{Results}

Submicroscopic structure of surface layer chondrocytes

In the surface layer, chondrocytes were elongated oval cells up to $10-15 \mu \mathrm{m}$ by $3-5 \mu \mathrm{m}$ in size. They were found in two or three rows parallel to the surface.

\section{Nucleus}

The nucleus was oval in shape with shallow invaginations in the nuclear envelope. The inner part of karyotheca was attached to the zonula nucleum limitans, varying in width, and a continuous layer of chromatin. Occasional karyosomes were distributed at random in the section (Plate I., Fig. 1), nucleoli were of reticular type. 


\section{Cytoplasm}

The granular endoplasmic reticulum presented as short flat cisternae filled with medium electron-dense material. The Golgi complex was well discernible and took a large part of the cytoplasm. The cisternae of its dictyosome released into the cytoplasm smooth vesicles which could be regarded as an agranular endoplasmic reticulum, and larger vacuoles with granular content. The latter functioned as transport vacuoles (Plates I., II. Figs 1, 3).

Mitochondria contained electron-dense material which made it difficult to distinguish their cristae. They included only occasional mitochondrial bodies. Most of the ribosomes were attached to the cisternae of granular endoplasmic reticulum. Free ribosomes either aggregated into rosettes or were scattered in the cytoplasm.

Intermediate filaments formed fine bundles seen near the nucleus, at the periphery of the cytoplasm or in cytoplasmic projections (Fig. 1).

Lysosomes and centrioles were frequent findings in the cytoplasm of these chondrocytes (Figs 1, 3).

Cell membrane. Infrequent short projections, no longer than $1 \mu \mathrm{m}$, were seen to extend from the part of cytoplasm turned towards the articular surface. They produced no branches and terminated at the intercellular matrix. Glycogen droplets were a regular part of the cytoplasm and were found as single beta granules or in clusters among other organelles (Figs 1, 3).

Submicroscopic structure of middle layer chondrocytes

The chondrocytes, circular or slightly oval, were deposited in the intercellular matrix of the middle layer as single cells (Plates III., IV., V. Figs 4, 5, 6). Their size was up to 12 by $10 \mu \mathrm{m}$.

\section{Nucleus}

The nucleus, its shape similar to the cell's shape, was situated excentrically. Its size was about $5 \mu \mathrm{m}$. The nuclear envelope showed only few shallow invaginations. The perinuclear space was usually narrow. Chromatin formed a continuous lining at the inner nuclear envelope (Figs 4,5) and small karyosomes were seen in cross-sections (Figs 5, 6). A reticular-type nucleolus with a distinct nucleolonemma was a frequent finding. A layer of perinuclear chromatin was clearly discernible (Plate III., Fig. 4).

\section{Cytoplasm}

The nucleus-to-cytoplasm ratio reflected the predominance of cytoplasm. Two types of cells could be distinguished according to the amount of granular endoplasmic reticulum in the cytoplasm. The first type was rich in the reticulum consisting of flat cisternae either scattered among the other organelles (Fig. 4) or occasionally arranged in tiers (Fig. 5). Cisternae contained medium to dense osmiophilic material (Plate IV., Fig. 5). icles.

The agranular endoplasmic reticulum was present as occasional smooth ves-

A small number of chondrocytes (second type) had only few short profiles of granular endoplasmic reticulum in the cytoplasm among the organelles (Fig. 6). The cisternae were either electron-transparent or filled with light fibrillar material. In the first type of cells, mitochondria were elongated with dark matrix showing distinct cristae (Figs 4,5), in the second cell type, they were regularly rod-shaped (Fig. 6). Free ribosomes were a frequent finding in the cytoplasm of the first chondrocyte type (Fig. 4). 
The Golgi apparatus was well developed and occupied a large region of the cytoplasm (Figs 4, 5,6). In the first type, some cisternae of its dictyosomes were enlarged (Figs 4,5), the other type was characterized by narrow cisternae but a large number of small Golgi vesicles. Both cell types contained in the cytoplasm high amounts of transport vacuoles with material of varying density (Figs 4, 5, 6) which was identified also outside the cell (Plate V. Fig. 6).

Lysosomes were often present in the cytoplasm of first type chondrocytes (Figs 4,5). Neither centrioles nor cilia were observed. Glycogen made large deposits (Figs 4,5) in the first type chondrocytes. The other chondrocytes showed small clusters of glycogen granules but they were more frequent and diffusely distributed in the cytoplasm (Fig. 6). These cells also often contained lipid droplets.

Intermediate filaments were more often seen in bundles near the nucleus than at the cell periphery (Figs 5,6).

Cell membrane. The cytoplasm of middle layer chondrocytes formed numerous branched projections along the whole circumference of the cell. The projections, up to $1-1.5 \mu \mathrm{m}$ in length, however, did not extend into the intercellular matrix (Figs 4, 5, 6).

\section{Submicroscopic structure of transitional zone chondrocytes}

In the intermediate zone of articular cartilage between middle and deep layers, the chondrocytes varied in appearance. The differences in ultrastructure were mostly due to different amounts of organelles. The size of the cells, however, was very similar to that seen in the middle layer.

\section{Nucleus}

The shape of the nucleus was similar to that of the cell, the size was about $3-5$ by $5-7 \mu \mathrm{m}$. The arrangement of chromatin and zonula nucleum limitans as well as the appearance of nucleoli were identical to those in the middle layer chondrocytes (Plate VI. Figs 7, 8).

\section{Cytoplasm}

Compared to the cytoplasm of chondrocytes in the middle layer, the nucleus-to-cytoplasm ratio changed in relation to an increased nuclear content (Figs 7,8 ). However, chondrocytes rich in cytoplasm similar to the middle layer cells could also be observed (Plate VII. Fig. 9). The granular endoplasmic reticulum consisted of short flat cisternae with light meshed content (Figs 7,9). The cisternae were most frequently found in the peripheral cytoplasm (Figs 7,8 ) or among organelles (Fig 9).

The agranular endoplasmic reticulum was a rare finding.

The Golgi apparatus was developed well only in the cells resembling those of the middle layer (Fig. 9). It extended over a large field and produced distinct vesicles filled with dark granular material (transport vacuoles) which remained close to the Golgi apparatus or were found near the cell membrane.

Mitochondria showed the usual structure with dark matrix. They occurred in low numbers and their size was $0.5-1.0 \mu \mathrm{m}$. Glycogen was found in both cell types in small clusters either in the peripheral cytoplasm (Figs 7,8) or scattered among organelles (Fig. 9).

In the chondrocytes characteristic of the transitional zone, bundles of intermediate filaments surrounded the nucleus; this was not observed in the cells resembling the middle layer chondrocytes. 
Cell membrane. The cytoplasm of these cells sent out only few short projections, up to $0.8-1.0 \mu \mathrm{m}$, extending into the pericellular matrix. Pinocytotic vesicles were few in number (Figs 7, 8,9). Occasional cilia were observed in the cells similar to the middle layer chondrocytes (Fig. 9).

\section{Submicroscopic structure of deep layer chondrocytes}

The chondrocytes had rounded triangular shapes and were found in lacunae, usually two in each (Plate VII. Fig. 10). Apart from these cells, chondrocytes at various stages of disintegration were frequently seen (Plate VIII. Figs 11, 12).

\section{Nucleus}

On cross-section, the nucleus had a roughly triangular shape with a narrow lining of cytoplasm (Fig. 10). Chromatin was arranged into many karyosomes, which gave the nucleus a dark appearance. The nucleolus was of reticular type.

\section{Cytoplasm}

Compared to the transitional zone chondrocytes, these cells had a low amount of cytoplasm with only a few organelles.

The granular endoplasmic reticulum presented as occasional flat cisternae which were randomly situated among organelles (Fig. 10).

The agranular endoplasmic reticulum was present as few smooth vesicles.

The Golgi apparatus was situated in a small region of the cytoplasm; its dictyosome released a low amount of small vesicles (Fig. 10) and transport vacuoles with electron-dense content.

Mitochondria were observed only on rare occasions. They were oval in shape with the usual structure, and measured up to $0.5 \mu \mathrm{m}$.

Glycogen was deposited as occasional granules or small clusters in the cytoplasm (Fig. 10).

Intermediate filaments occurred in bundles occasionally found near the nucleus (Fig. 10).

Cell membrane. The cytoplasm formed projections, about $1.5 \mu \mathrm{m}$ long, on the surface turned to the neighbouring chondrocyte, while the remaining surface was smooth (Fig. 10). Neither desmosomes nor cilia were observed in the cells of the deep layer.

Disintegrating chondrocytes were present in two typical appearances. The first one contained remains of cytoplasm with a large amount of vesicular structur :s varying in size and containing clusters of glycogen (Fig. 11). Some areas were membrane-free and thus in contact with the pericellular matrix. The second one showed homogeneous cytoplasm with the debris- of granular endoplasmic reticulum, large deposits of glycogen and big lipid vacuoles filling almost the whole cell (Fig. 12).

\section{Intercellular matter}

Two components could be distinguished: pericellular matrix and intercellular matrix. The surface of the articular cartilage showed typical collagenous fibrils running mostly parallel to the surface and occasionally forming bundles (Fig. 2). Among the collagenous fibrils and near to the pericellular matrix were bundles of fine aperiodic filaments giving rise to the typical collagenous fibrils (Fig. 3). The pericellular matrix (Figs 1,3) consisted of fine particulate and/or filamentous material with medium-electron density. This area often contained remnants of cell organelles (Fig. 1). 
In the middle layer, the pericellular matrix was very distinct. It was filled with fine filaments without periodicity. At the border with the intercellular matrix there was a considerable number of round bodies, each enveloped with a smooth membrane. Their content varied in density. (Figs 4, 5, 6). Cross and tangential sections through cytoplasmic projections could also be observed (Figs 4,6).

The pericellular matrix of the transitional zone was arranged in a manner similar to that in the surface and middle layers (Figs 7, 8, 9).

In the deep layer, the region of pericellular matrix was rather narrow, with aperiodic fibrils only between the chondrocytes enclosed in lacunae (Fig. 10). The intercellular matrix was composed of dense network of collagenous fibres which, arranged in bundles, ran around lacunae containing chondrocytes. In the areas of disintegrating chondrocytes, the pericellular matrix disappeared and the region was gradually filled with collagenous fibres (Figs 11, 12). The cell projections which remained preserved (Fig. 12) were then found in the intercellular matrix. The areas with disintegrating cells showed cell debris and cross-sections of cytoplasmic projections (Fig. 11).

\section{Discussion}

While in small laboratory animals the microscopic and submicroscopic structure of articular cartilage has received considerable attention (see Ghadially 1983; Horký 1980) in large farm animals the relevant data are scarce. Our earlier work was concerned with articular cartilage in cattle (Horký 1983, 1986) and swine during ontogenesis (Horký 1989, 1991d). The ultrastructure of porcine articular cartilage in physiologic conditions has been studied by Nakano et al. (1979a, 1982), Wilsman et al. (1981) and Bhatnagar et al. (1981). Even before there were studies on the blood supply to the skeletal blastema and articular cartilage related to degenerative processes (Levene 1964; Lufti 1970; Denecke and Trautwein 1986; Burch and Lebowitz 1982; Farnum et al. 1984) and on the effect of nutrition, sex and hormones on the occurrence of cartilage lesions (Nakano et al. 1979b).

Much more attention has been given to the histological changes due to osteochondrosis and arthrosis in the pig (Grondalen 1974a, b, c, d, e, f; Grondalen and Grondalen 1974; Nakano et al. 1982; Denecke et al. 1985).

With respect to specialized functioning of the joint, microscopic observations of the articular cartilage structure has mostly been focused on its thickness, the density and distribution of chondrocytes particularly in the surface layer ( $\mathrm{Si}$ mon 1971; Gilmore and Palfrey 1987, 1988). The authors has found, in accordance with the general view, that the position of chondrocytes is influenced by pressure forces acting on the cartilage. Chondrocytes are under pressure during the development of intercellular matrix (Gould et al. 1974) and, in the prenatal period particularly, under pressure exerted by muscles which develop before the articular fissure is formed.

In the surface layer, the chondrocytes of porcine articular cartilage do not differ from those described in other mammals (Horký 1980; 1987). They are characterized by large lysosomes and a well-formed Golgi apparatus, as has been observed in articular cartilage of the postnatal period (Horký 1991 d). In contrast to that period, however, the pericellular matrix in adult pigs showed granulated matter and remnants of cell organelles (Horký 1991d). The zonula nucleum limitans in the adult as compared to the postnatal pig was quite distinct (Horký 
$1986,1987,1991$ d). We differ from Oryschak et al. (1974) in suggesting that the thickness of this structure does not depend entirely on the physiological state of the cells but is also related to age. The presence of large numbers of organelles involved in intercellular matrix formation is a general feature of the chondrocytes in the middle layer (for review see Horky 1991d). Of interest is the finding of glycogen deposits which exist in the cells as early as at birth (Horký 1991d). Some of the glycogen is subject to degradation manifested by clusters of vacuoles or formation of glycogenosomes (Horký 1991d). The presence of high amounts of glycogen, however, should not be interpreted as indicative of synthesis. On the contrary, glycogen accumulation is the result of its unsufficient utilization and a reduction in synthetic activity (Ghadially 1983). The important role of the middle layer in metabolic proceses is evidenced by many organelles and an increased occurrence of transport vacuoles.

In contrast to the prenatal (Horký 1989) and early postnatal periods (Horký 1991d), the adult articular cartilage in the pig shows a layer referred to as transitional zone. This has not been observed in any of the mammalian species investigated before (Horky 1983, 1986, 1990). The cytoplasm of the cells has conspicuous bundles of intermediate filaments which run around the nucleus.

The adult articular cartilage showed further differentiation and maturation of the surface layer and intercellular matrix. While in the early post-fertilization stages (Horký 1989) the cartilage surface is made up of aperiodic fibrils and a large amount of ground amorphous substance, with increasing prenatal age the intercellular matrix is getting thicker due to formation of typical collagenous fibres. At birth the surface as well as the other layers are fully capable of functioning in the joint (Horký 1991d). In the period till adulthood, the collagenous fibres in the surface layer aggregate into bundles which cross perpendicular to each other, as has been observed earlier (Horký 1983, 1987). The chondrosynovial membrane (Wolf 1975) is complete since birth (Horký 1991d).

\section{Submikroskopická struktura kloubní chrupavky prasete v dospělosti}

Byla studována kloubní chrupavka 5 jedinců obojího pohlaví stáŕi $14-24$ měsíců. Pro účely světelné, transmisní a rastrovací elektronové mikroskopie byla odebírána chrupavka $\mathrm{z}$ hlavice kyčelního kloubu a zpracována obvyklým způsobem.

Chondrocyty povrchové vrstvy maji oválný tvar, do okolní pericelulárni matrix vysílají krátké výběžky. V cytoplasmě obsahují větši počet lysosomů, transportní vakuoly, centriol a nápadně dobře vytvořený Golgiho komplex a malé shluky glykogenu. Jsou uloženy v $1-2$ řadách nad sebou.

Chondrocyty střední vrstvy jsou oválné buňky, uložené po $1-2 \mathrm{v}$ lakunách. Jádro obsahuje $1-2$ jadérka retikulárního typu, je vytvořena zonula nucleum limitans. V cytoplasmě je velké množství mitochondrií, cisteren granulárního endoplasmatického retikula, velká Golgiho pole, četné transportní vakuoly, lysosomy a nápadná depozita glykogenu.

Ve vrstvě přechodní jsou chondrocyty seřazeny do sloupců kolmo $\mathrm{k}$ povrchu. Jsou poněkud menších rozměrů, $v$ cytoplasmě kromě obvyklých organel se vyskytují mohutné svazky intermediárních filament. V hluboké vrstvě se vyskytují jednak chondrocyty s nápadně velkými tukovými vakuolami, jednak s homogenní cytoplasmou a malými shluky glykogenu.

Pericelulárni matrix je $u$ většiny chondrocytů vytvořena zřetelně; $v$ některých 
úsecích však chybí a buněčná membrána je $\mathrm{v}$ kontaktu $\mathrm{s}$ intercelulární matrix. Zvláště ve vrstvě střední na hranici mezi peri- a intercelulární matrix je uložen buněčný detritus.

\section{Субмикроскопическая структүра сүставного хряща свиней в зрелом возрасте}

Проводили исследования суставного хряща. 5 особей обоего пола .В возрасте 14-24 месяцев. Для целей световой, трансмиссионной м растровой электронной микроскопии проводили отбор хряща на головке тазобедренного сустава и обрабатывали обычным приемом.

Хондроциты поверхностного слоя отличаются овальной формой, в окружающую перицеллюлярную основу выходят короткие выступы. В цитоплазме они содержат большее число лизосом, транспортные вакуоли, центриоли и весьма хорошо образованный комплекс Гольджи, а также небольшие скопления гликогена. Они расположены в 1 - 2 рядах друг над другом.

Хондроциты среднего слоя - овальные клетки, по 1-2 расположенные в лакунах. Ядро содержит 1-2 плазмосомы ретикулярного типа, образована zonula nucleum limitans. В цитоплазме находятся большое количество митохондрий, цистерн гранулярной эндоплазматический сеточки, большие поля Гольджи, многочисленные транспортные вакуоли, лизосомы и бросающиеся в глаза отложения гликогена.

В переходном слое хондроциты сформированы в колоны перпендиזкулярно к поверхности. Они небольших размеров, в цитоплазме помимо обычных органелл встречаются мощные пучки промежуточных ннтей. В глубоком слое находятся не только хондроциты с крупными жировыми вакуолями, но и с однородной цитоплазмой и небольшими скоплениями гликогена.

Перицеллюлярная основа у большинства хондроцитов сформирована четко, однако на некоторых участках она отсутствует и клеточная мембрана находится в контакте с межклеточной основой. В особенности в среднем слоем, между пери- и интерцеллюлярной основой расположен клеточный детрит.

\section{References}

BARNETT, C. H.-COCHRANE, W.-PALFREY, A. J.: Age changes in articular cartilage of rabbits. Ann. rheum. Dis., 22, 1963: 389-400

BHATNAGAR, R.-CHRISTIAN, R. G.-NAKANO, T.-AHERNE, F. X.-THOMPSON, J. R.: Age related changes and osteochondrosis in swine articular and epiphyseal cartilage: Light and electron microscopy. Can. J. Comp., Med., 45, 1981 : 188-195

BLOEBAUM, R. D. - WILSON, A. S.: The morphology of the surface of articular cartilage in adult rats. Am. J. Anat., 131, 1980: 333-346

BONUCCI, E.: Fine structure of early cartilage calcification. J. Ultrastruct. Res., 20, 1967: 33-45

BUCKWALTER, J. A. - SMITH, K. C. - KAZARIEN, L. E.-ROSENBERG, L. C. - UNGAR, R.: Articular cartilage and intervertebral disc proteoglycans differ in structure: An electron microscopic study. J. Orthop. Res., 7, 1989:146-151

BURCH, W. M.-LEBOVITZ, H. E.: Triiodothyronine stimulates maturation of porcine growth - plate cartilage in vitro. J. Clin. Invest., 70, 1982: 496-504

CLARK, J. M.: The organisation of collagen fibrils in the superficial zones of articular cartilage. J. Anat., 171, 1990: 117-130 
CLAR KE, I. C.: Articular cartilage: a review and scanning electronmicroscope study. II. the territorial fibrillar architecture. J. Anat. (London), 118, 1974: 261-280

COPF, F.-CZARNETZKI, A.: Die hydrodynamische Komponente im Gelenk: nachweis eines Membranen-Zysternen-Systems in der Kalzifizierten Zone des Knorpels am Femurkopf. Acta Anat., 136, 1989: 248-254

DAVIES, D. V.-BARNETT, C. H.-COCHRANE, W.-PALFREY, A. J.: Electron microscopy of articular cartilage in the young adult rabbit, Ann. rheum. Dis., 21, 1962: 11-22

DENECKE, R. - KAUP, F. J.-MEYER, M.: Intercellular network in articular cartilage of pigs with experimentally induced arthritis. I. Fact or artifact? Rheumatol. Int., 576, 1985: $265-271$

DENECKE, R.-TRAUTWEIN, G.: Articular cartilage canals - a new pathogenetic mechanism in infectious arthritis. Experientia, 42, 1986: 999-1 001

DOIGE, C. E.: Pathological changes in the lumbar spine of boars. Can. J. comp. Med., 44, 1980: $382-389$

FARNUM, C. E.-WILSMAN, N. J.-HILLEY, H. D.: An ultrastructural analysis of osteochondritic growth plate cartilage in growing swine. Vet. Pathol., 21, 1984: 141-151

FREEMAN, M. A. R. - KEMPSON, G. E.: Load carriage. In: Adult articular cartilage, pp. 228-264, M. A. R. Freeman (ed.), Alden Press, Oxford, Great Britain, 1973

FIFE, R. S.: Comparison of a 550000 dalton cartilage matrix glycoprotein in cartilage from immature and mature dogs. J. Rheumatol., 16, 1989: 656-660

GARDNER, E.-O'RAHILLY, R.: The early development of the knee joint in staged human embryos. J. Anat. (London), 102, 1968: 289-299

GHADIALLY, F. N.: Structure and function of articular cartilage. Clin. rheum. Dis., 7, 1981: $3-28$

GHADIALLY, F. N.: Fine structure of synovial joints. Butterworths, London 1983

GILMORE, C. R. ST.-PALFREY, A. J.: Chondrocyte distribution in the articular cartilage of human femoral condyles. Am. J. Anat., 157, 1988: 23-31

GOULD, R. P.-SELWOOD, L.-DAY, A.: The mechanism of cellular orientation during early cartilage formation in the chick limb and regenerating amphibian limb. Exp. Cell Rec., 83, 1974: 287-296

GRONDALEN, T.: Osteochondrosis and arthrosis in pigs. I. Incidence in animals up to $20 \mathrm{~kg}$ live weight. Acta vet. Scand., 15, 1974a: 1-25

GRONDA LEN; T.: Osteochondrosis and arthrosis in pigs. II. Incidence in breeding animals. Acta vet. Scand., 15, 1974b: $26-42$

GRONDALEN, T.: Osteochondrosis and arthrosis in pigs. III. A comparison of the incidence in young animals of the Norwegian Landrace and Yorkshire breeds. Acta vet. Scand., 15, 1974: $43-52$

GRONDALEN, T.: Osteochondrosis and arthrosis in pigs. VI. Relationship to feed level and calcium phosphorus and protein levels in the ration. Acta vet. Scand., 15, 1974d: 147-169

GRONDALEN, T.: Osteochondrosis and arthrosis in pigs. VII. Relationship to joint shape and exterior conformation. Acta vet. Scand., 15, (Suppl. 46), 1974e: 1-32

GRONDALEN, T:: Osteochondrosis, arthrosis and leg weakness in pigs. Nord. vet. Med., 26, 1974f: $534-537$

GRONDALEN, T. - GRONDALEN, J.: Osteochondrosis and arthrosis in pigs. IV. Effect of overloading on the distal plate of the ulna. Acta vet. Scand., 15, 1974: 53-60

GRONDALEN, T. - VANGEN, O.: Osteochondrosis and arthrosis in pigs. V. Comparison of the incidence in three different lines of the Norwegian Landrace Breed. Acta vet. Scand., 15, 1974: $61-79$

HANAOKA, H.: The fate of hypertrophic chondrocytes of the epiphyseal plate. An electron study. J. Bone Jt. Surg., 58, 1976: 226-229

HORKY, D.: Submicroscopic structure of the human joint cartilage. Acta vet. Brno, 49, 1980: $145-176$

HORKYY, D.: Ontogenic development of the ultrastructure of bovine joint cartilage. Acta vet. Brno, 52, 1983: 103-130

HORKÝ, D.: Ultrastructure of bovine articular cartilage between weeks 8 and 23 of prenatal development. Acta vet. Brno, 55, 1986: 227-246

HORKY, D.: Submicroscopic structure of bovine articular cartilage in prenatal and early postnatal period. Acta vet. Brno, 56, 1987: 3-18

HORKY, D.: The ultrastructure of articular cartilage in the prenatal pig. Acta vet. Brno, 58, 1989: $143-174$

HORKÝ, D.: Submicroscopic structure of articular cartilage in human embrya six to eleven weeks old. Acta vet. Brno, 60, 1991a: 15-30

HORKÝ, D.: Submicroscopic structure of human articular cartilage in the period between 19 to 38 weeks after fertilization. Acta vet. Brno, 60, 1991b: 111-126 
HORKÝ, D.: The submicroscopic structure of articular cartilage in swine in the early postnatal period. Acta vet. Brno, 60, 1991d: 323-334

CHAPPUIS, J. - SHERMAN, I. A.-NEUMANN, A. W.: Surface tension of animal cartilage as it relates to function in joints. Ann. Biomed. Eng., 11, 1983: 435-451

KIEFER, G. N.-SUNDBY, K.-McALLISTER, D.-SHRIVE, N. G.-FRANK, C. B.LAM, T. - SCHACHAR, N. S.: The effect of cryopreservation on the biomechanical behavior of bovine articular cartilage. J. Orthop. Res., 7, 1989: 494-502

LEVENE, C.: The pattern of cartilage canals. J. Anat. (London), 98, 1964: 515-538

LUFTI, A. M.: The mode of growth, fate and function of cartilage canals. J. Anat. (London), 106, 1970: $135-145$

LUST, G.-PRONSKY, W.-SHERMAN, D.: Biochemical and ultrastructural observations in normal and degenerative canine articular cartilage. Am. J. vet. Res., 33, 1972: 2 429-2 440

LUST, G.-SHERMAN, D. M.: Metabolic and ultrastructural studies on articular cartilage of developing canine hip joints. Cornell Vet., 63, 1973: 94-104

MARK, M. P.-BUTLER, W. T.-RUCH, J. V.: Transient expression of chondroitin sulfate-related epitope during cartilage histomorphogenesis in the axial skeleton of rats. Develop. Biol., 133, 1989: 475-489

MAROUDAS, A.: Physico-chemical properties of articular cartilage. In: Adult articular cartilage. M.A.R. Freeman, Alden Press, Oxford 1973

NAKANO, T. - AHERNE, F. X.-THOMPSON, J. R.: Changes in swine knee articular during growth. Can. J. Anim. Sci., 59, 1979a: 167-179

NAKANO, T.-AHERNE, F. X.-THOMPSON, J. R.: Effects of feed restriction, sex and diethylstilbestrol on the occurrence of joint lesions with some histological and biochemical studies on the articular cartilage of growing-finishing swine. Can. J. Anim. Sci., 59, 1979b: $491-502$

NAKANO, T.-THOMPSON, J. R.-AHERNE, F. X.: Molecular size of chondroitin sulfate from normal and osteochondritic joint cartilage of adolescent boars. Can. J. comp. Med., 46, 1982: 395-399

NEAME, P. J.-CHOI, H. U.-ROSENBERG, L. C.: The primary structure of the core protein of the small, leucine-rich proteoglykan (PGI) from bovine articular cartilage. J. Biol. Chem., 264, 1989: 8646-8 653

O'CONNOR, P.-BRERETON, J. D.-GARDNER, D. L.: Hyaline cartilage disected by papain-light and scannig microscopy and micromechanical studies. Ann. rheum. Dis., 43, 1984: $320-327$

ORYSCHAK, A. F.-GHADIALLY, F. N.-BHATNAGAR, R.: Nuclear fibrous lamina in the chondrocytes of articular cartilage. J. Anat (London), 118, 1974: 511-515

PALMOSKI, M. J. - BRANDT, K. D.: Effects of static and cyclic compresive loading on articular cartilage plugs in vitro. Arthritis Rheum., 27, 1984: 675-682

PERRIN, W. R.-AHERNE, F. X.-BOWLAND, J. P.-HARDIN, R. T.: Effects of age, breed and floor type on the incidence of articular cartilage lesions in pigs. Can. J. Anim. Sci., 58, 1978: $129-138$

POOLE, C. A.-WOTTON, S. F.-DUANCE, V. C.: Localization of type XI collagen in chondrons isolated from porcine articular cartilage and rat chondrosarcoma. Histochem. J., 20, 1988: $567-574$

SILBERGER, R. - SILBERGER, M.-VOGEL, A.-WETTSTEIN, W.: Ultrastructure of articular cartilage of mice of various ages. Am. J. Anat., 109, 1961: 251-375

SILBERGER, R. - HASLER, M.-LESKER, P.: Ultrastructure of articular cartilage of achondro lastic mice. Acta Anat. (Basel), 96, 1976: 162-175

SIMON, W. H.: Scale effects animal joints. II. Thickness and elasticity in the deformability of articular cartilage. Arthritis Rheum., 14, 1971: 493-502

SWANN, D. A.-BLOCH, K. J.-SWINDELL, D.-SHORE, E.: The lubricating activity of human synovial fluid. Arthritis Rheum., 27, 1984: 552-557

WEISS, C. - ROSENBERG, L.-HELFERT, A. J.: An ultrastructural study of normal young adult human articular cartilage. J. Bone Jt. Surg., 50A, 1968: 663-674

WILSMANN, J.-FARNUM, C. E.-HILLEY, H. D.-CARLSEN, C. S.: Ultrastructural evidence of a functional heterogeneity among physeal chondrocytes in growing swine. Am. J. Vet. Res., 42, 1981: 1 547-1553

WILTBERGER, H. - LUST, G.: Ultrastructure of canine articular cartilage: comparison of normal and degenerative (osteoarthritic) hip joints. Am. J. Vet. Res., 36, 1975: 727-740

WOLF, J.: Function of chondral membrane on surface of articular cartilage from point of view of its mechanical resistance. Folia morphol. (Prague), 23, 1975: 77-87

WRIGHT, V.: Lubrication and wear in joints. Sector Publ. Lim., London 1969 


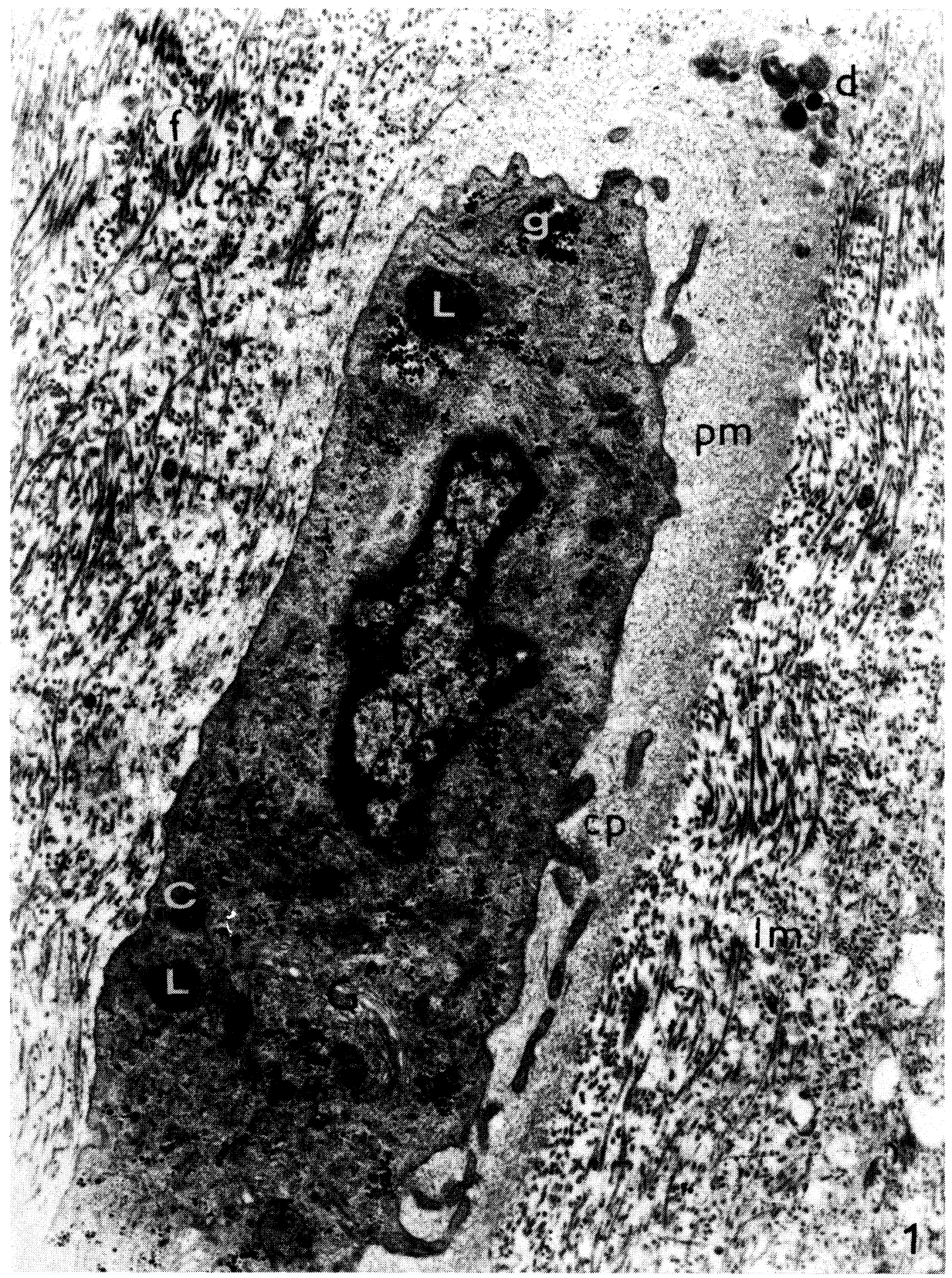

Fig. 1: Chondrocytes of the surface layer of articular cartilage. Nucleus $(\mathrm{N})$, zonula nucleum limitans $(\mathrm{Z})$, mitochondria (M), lysosomes (L), centriole (c), Golgi apparatus (G), glycogen (g), transport vacuole $(\mathrm{T})$, cytoplasmic projections ( $\mathrm{cp}$ ) extending into pericellular matrix (pm). Intercellular matrix (Im) with collagenous fibrils (f). Intracytoplasmic filaments $(\rightarrow)$. Cell detritus (cd). $\times 16000$. 
Plate II.

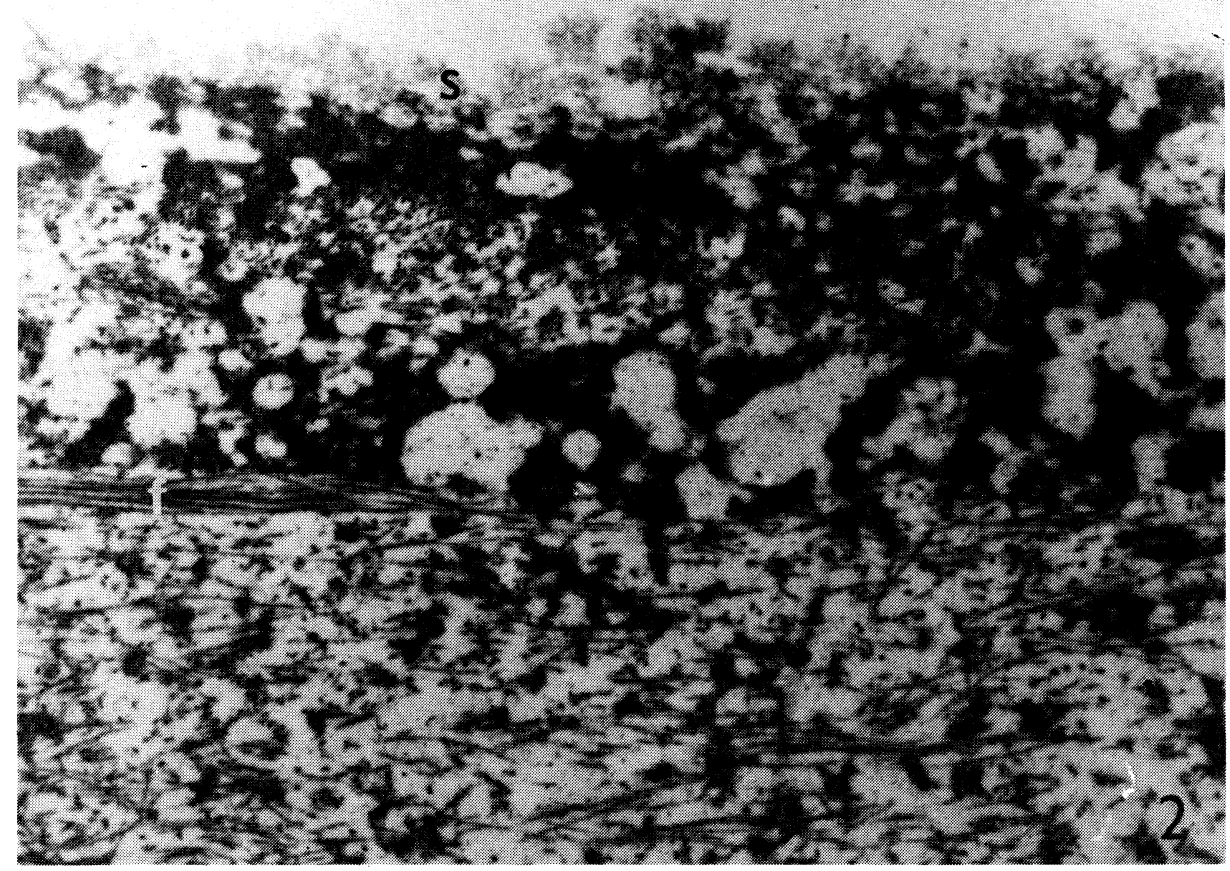

Fig. 2: The surface of articular cartilage. Remains of synovial fluid (s) on the surface of chondrosynovial membrane. Collagenous fibrils (f) in bundles parallel the surface and single fibrils running at various directions. $\times 14000$.

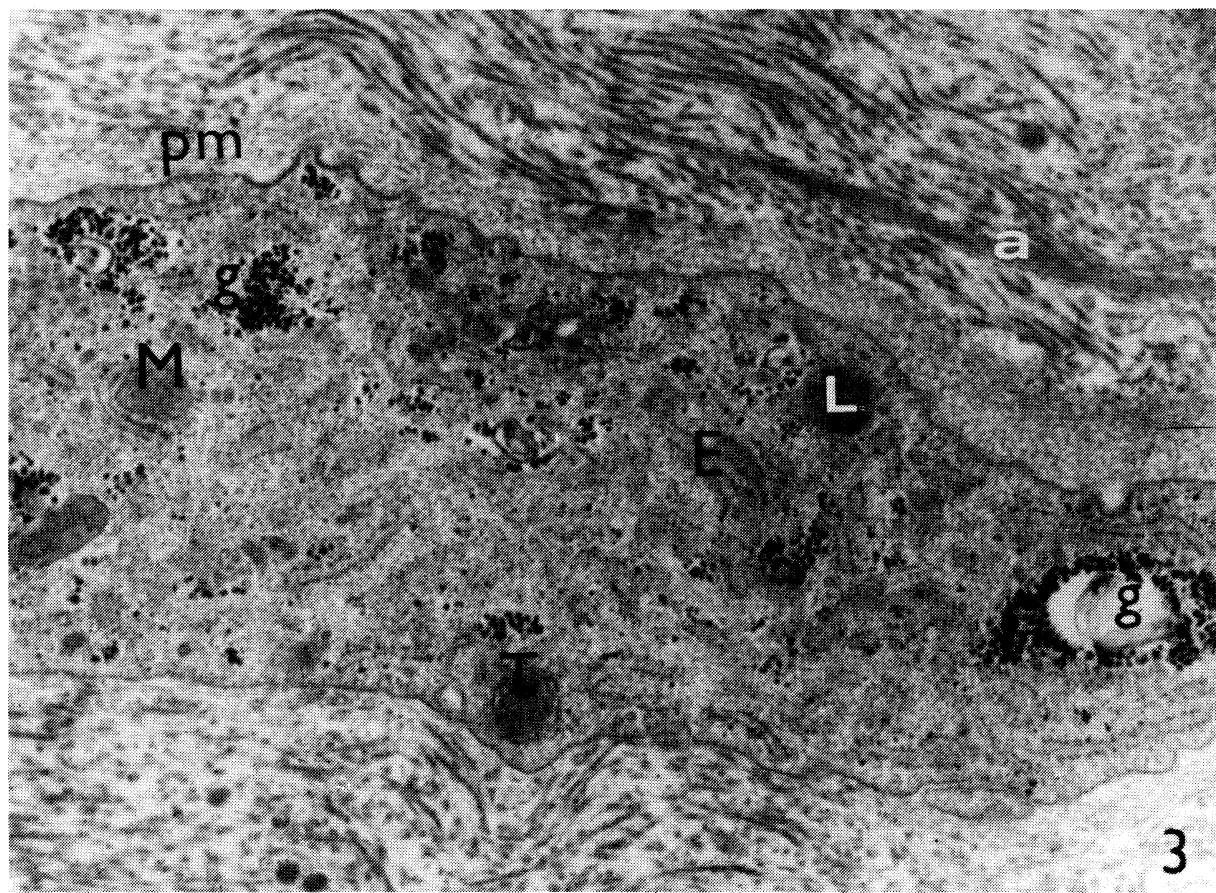

Fig. 3: Chondrocytes of the surface layer. Mitochondria (M), lysosomes (L), transport vacuole (T), granular endoplasmic reticulum (E). Glycogen aggregates $(\mathrm{g})$. Pericellular matrix (pm), a bundle of aperiodic fibrils (a) in the intercellular matrix. $x 13000$. 
Plate III.

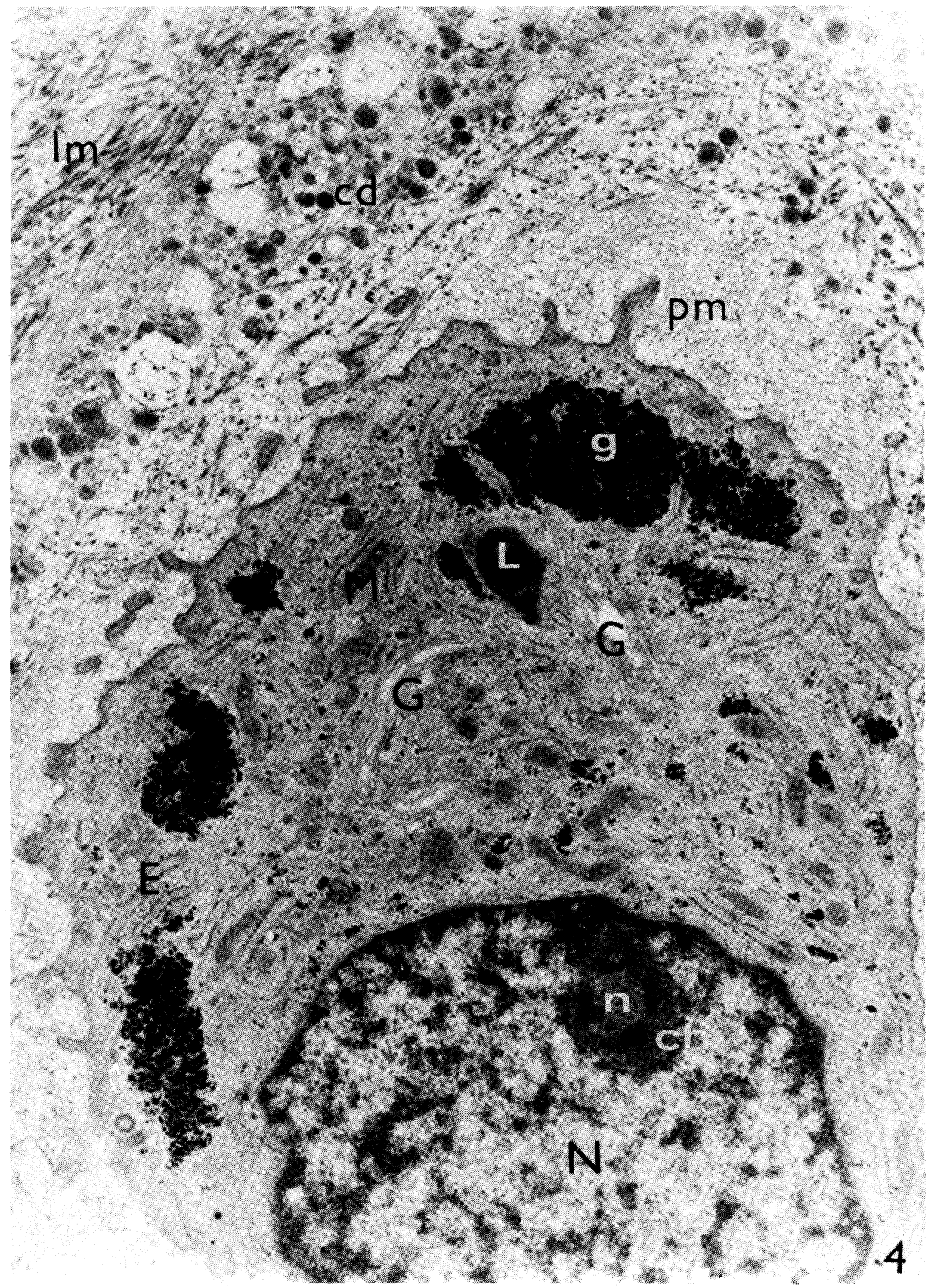

Fig. 4: Chondrocytes of the middle layer. Nucleus (N), nucleolus (n) with perinucleolar chromatin (ch). Granular endoplasmic reticulum (E), mitochondria (M), Golgi apparatus (G), lysosome (L), glycogen deposits $(\mathrm{g})$. Cell detritus $(\mathrm{cd})$ between pericellular $(\mathrm{pm})$ and intercellular $(\mathrm{Im})$ matrix. $\times 16500$. 
Plate IV.

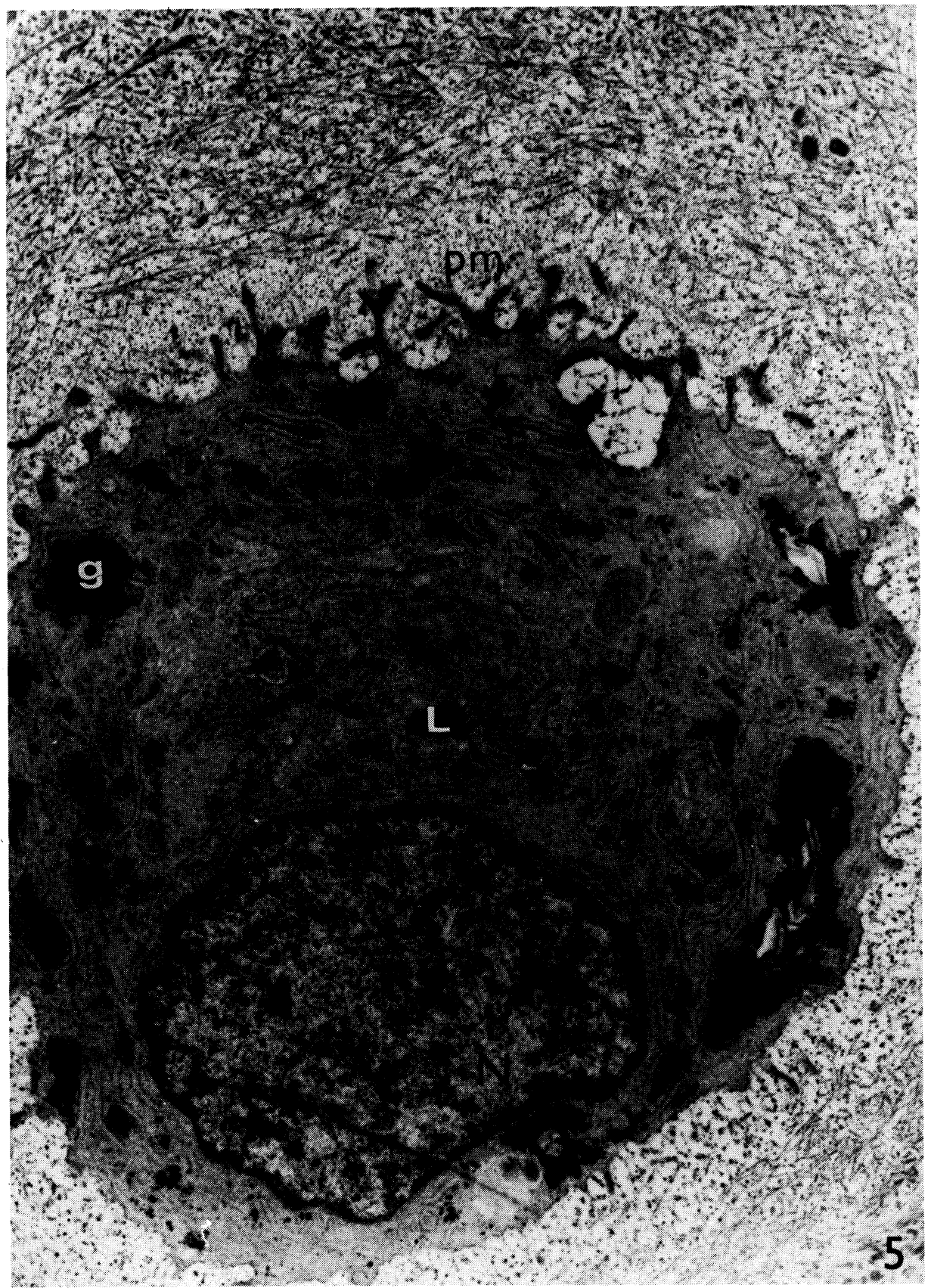

Fig. 5: Chondrocytes of the middle layer. Nucleus $(\mathrm{N})$, numerous cisternae of granular endoplasmic reticulum (E), lysosomes (L), transport vacuoles $(\mathrm{T})$, glycogen deposits $(\mathrm{g})$. Numerous cytoplasmic projections extend only up to the pericellular matrix $(\mathrm{pm}) . \times 12000$ 


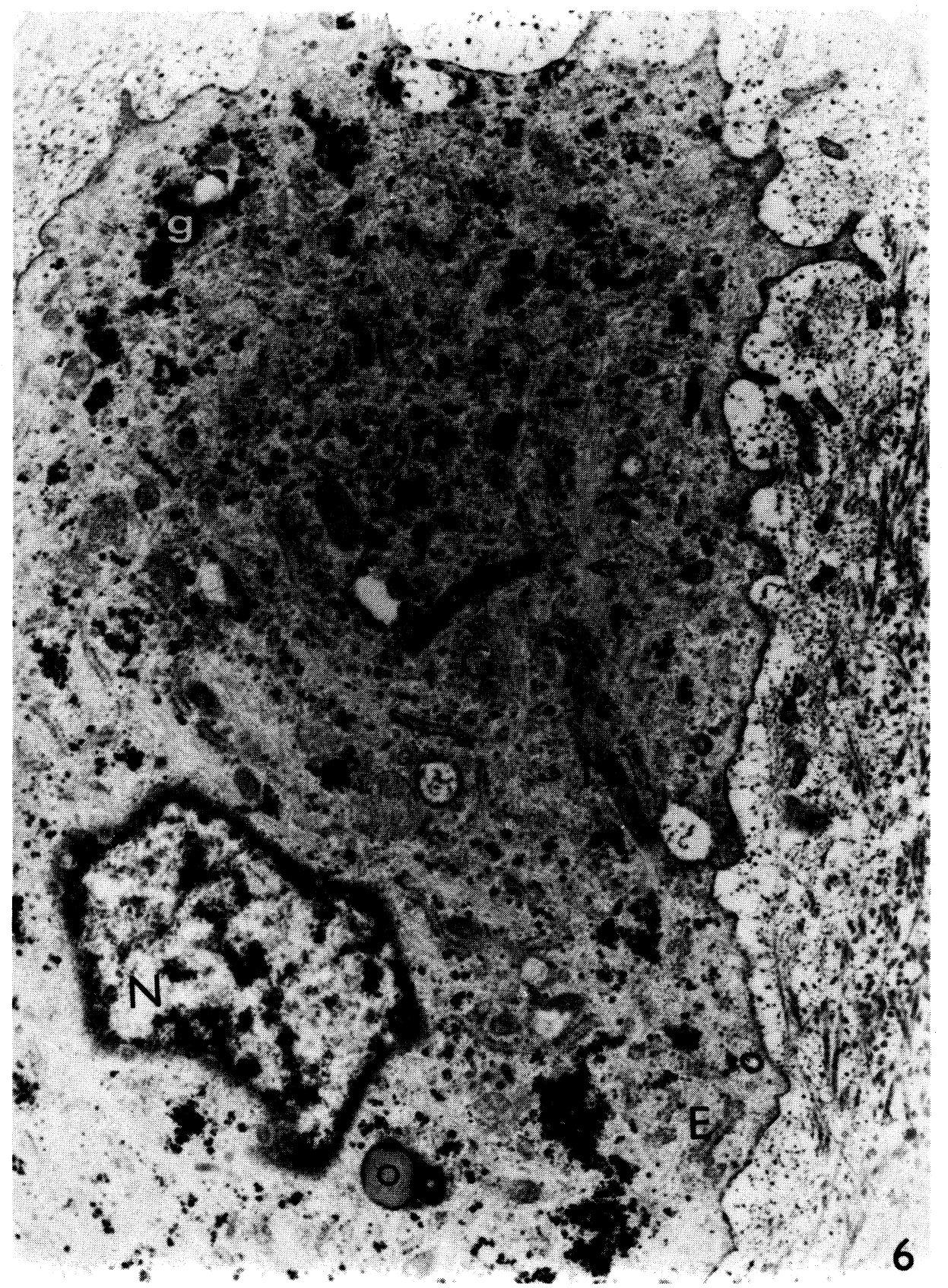

Fig. 6: A chondrocyte of the middle layer. Nucleus (N), rod-shaped mitochondria (M), short cisternae of granular endoplasmic reticulum (E), Golgi apparatus with fine vesicles $(\mathrm{G})$, transport vacuoles (T), lipid droplets (o), small glycogen deposits (g), intracytoplasmic filaments $(\rightarrow)$. $\times 16500$. 


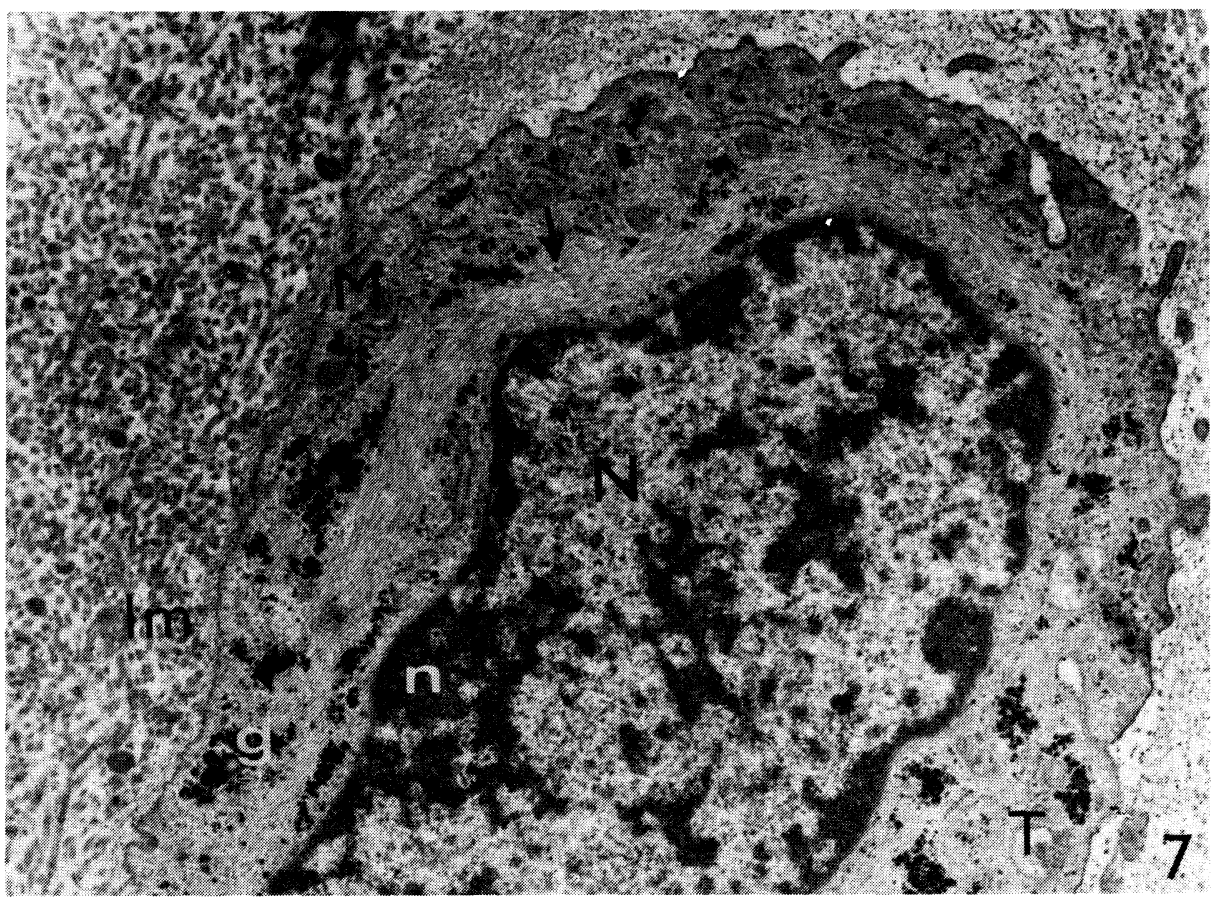

Fig. 7: Chondrocytes of the transitional zone. Nucleus (N), nucleolus (n), small mitochondria (M), transport vacuole $(\mathrm{T})$, a big bundle of intracytoplasmic filaments $(\rightarrow)$, small clusters of glycogen $(\mathrm{g})$. Intercellular matrix $(\mathrm{Im})$ in some areas adjacent to the cell membrane. $\times 16000$.

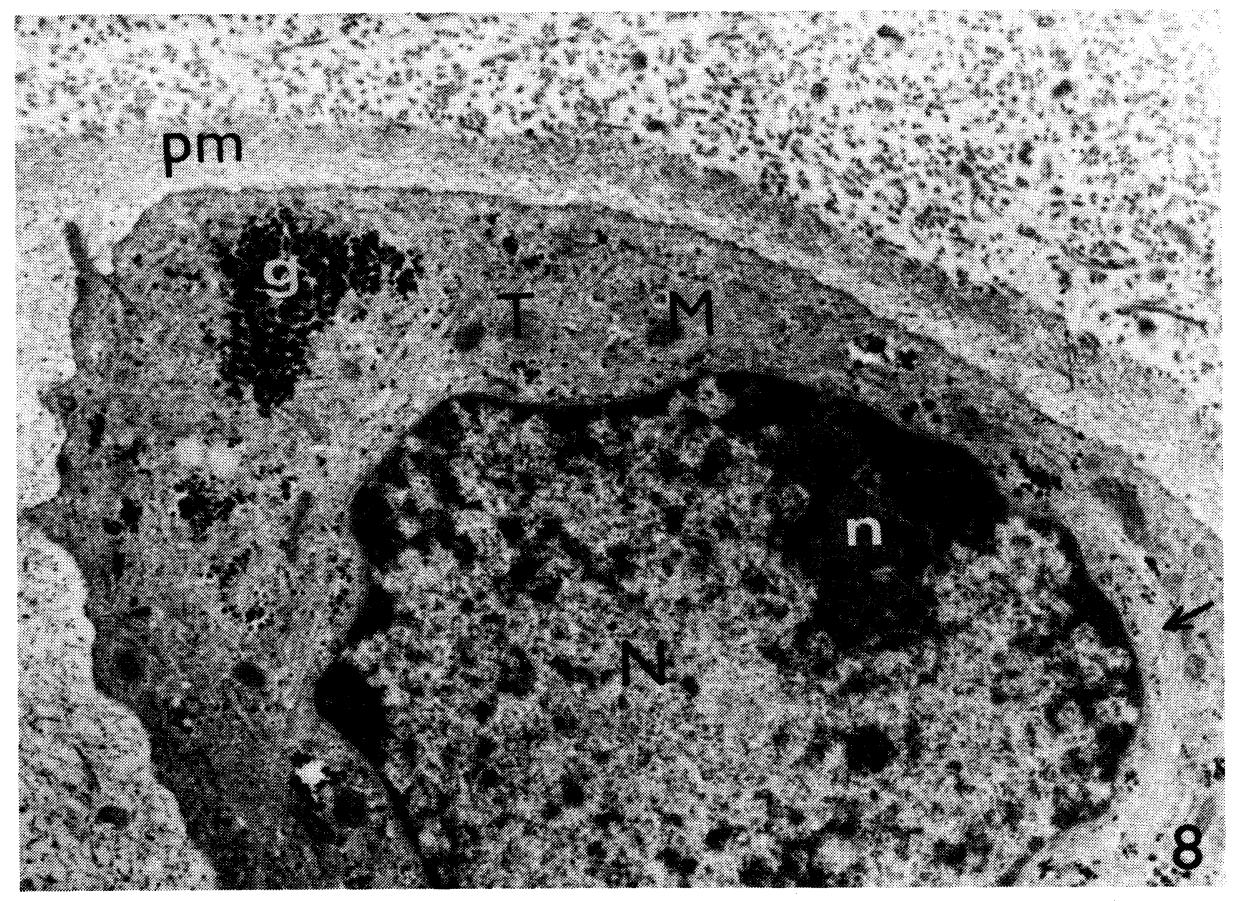

Fig. 8: Chondrocytes of the transitional zone. Nucleus $(\mathrm{N})$ with a nucleolus of reticular type (n), small mitochondria $(\mathrm{M})$, transport vacuole $(\mathrm{T})$, intracytoplasmic filaments $(\rightarrow)$, glycogen $(\mathrm{g})$. Pericel- 


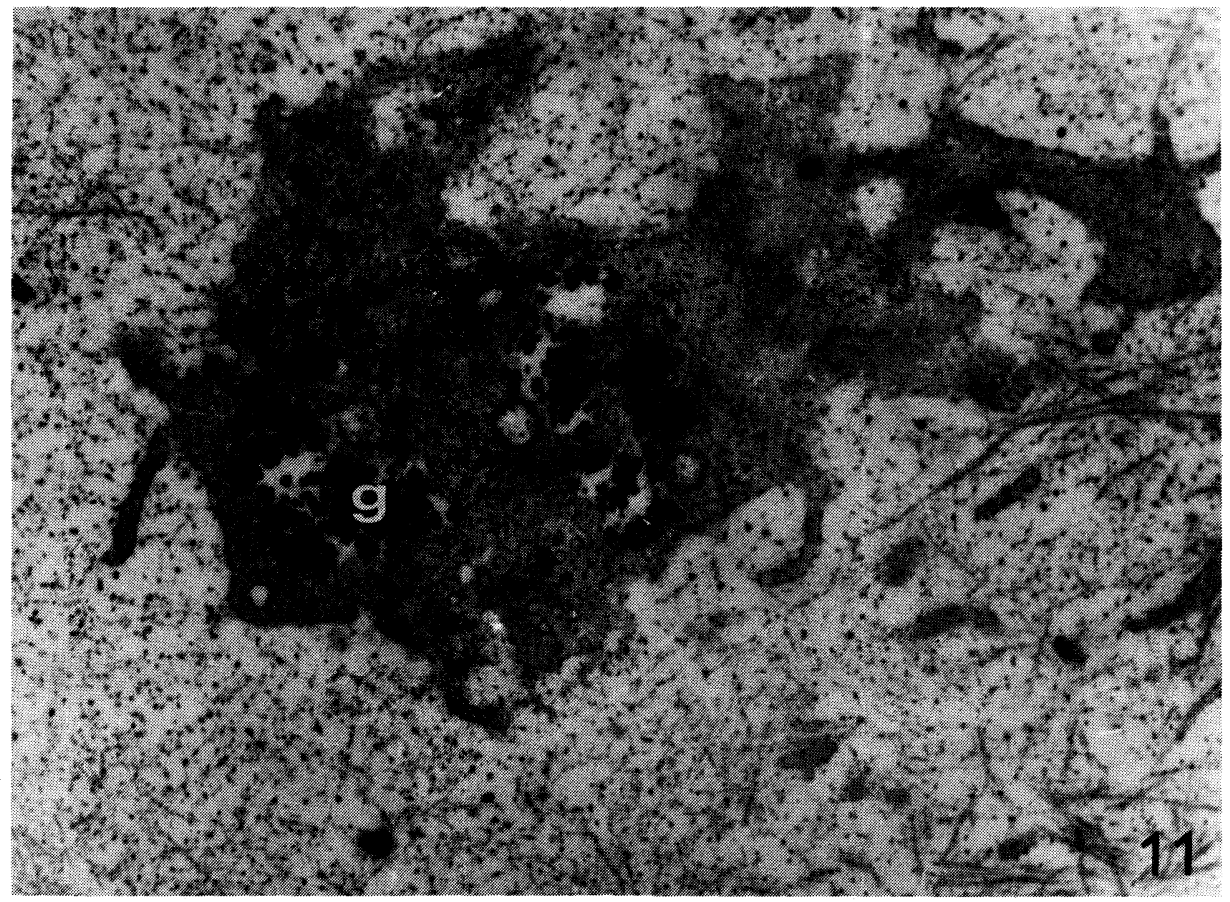

Fig. 11: A disintegrating chondrocyte of the deep layer. Homogeneous cytoplasm with numerous vesicular structures $(\mathrm{V})$, glycogen deposits (g). Pericellular matrix in direct contact with the cyto$\operatorname{plasm}(\rightarrow) . \times 18000$.

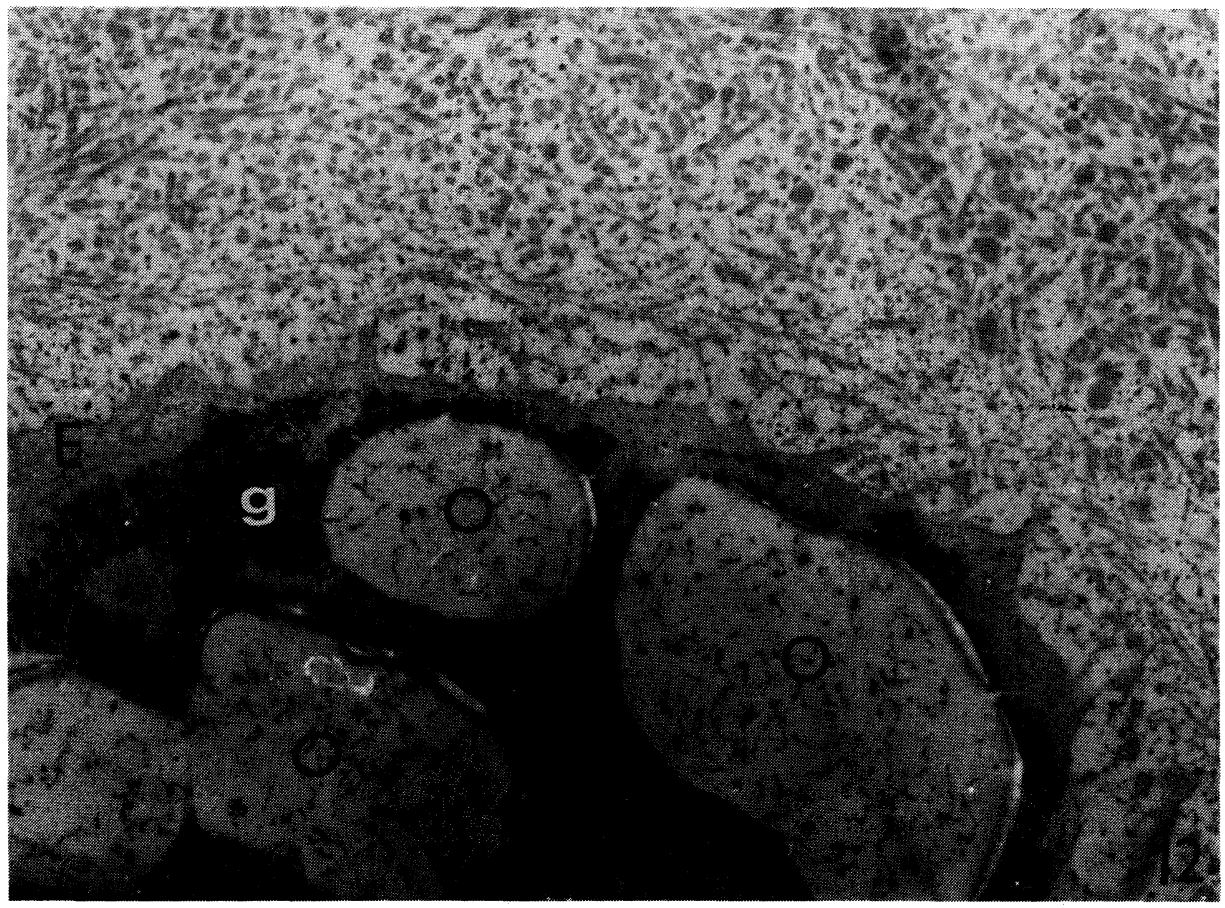

Fig. 12: A disintegrating chondrocyte of the deep layer. Short cisternae of the granular edoplasmic reticulum (E), large deposits of glycogen (g), big lipid vacuoles (o). $\times 16000$. 